\title{
Pemanfaatan Aplikasi TikTok Sebagai Media Pembelajaran Musik di SMAN 1 Muara Enim, Sumatera Selatan
}

\author{
Dian Herdiati ${ }^{1}$, Dhika Dwi Atmaji ${ }^{2}$, Raden Mas Aditya Andriyanto ${ }^{3}$, Dani Nur Saputra ${ }^{4}$ \\ 1,2,3,4 Universitas Negeri Jakarta \\ Email: dherdiati@unj.ac.id
}

\begin{abstract}
The ongoing pandemic conditions until now, causing the learning process to be done online. Online learning seems boring because the online learning methods and media that are applied are less creative and varied. Teachers' incompetence in using technology is one of the causes of boring learning, so schools and teachers are trying to find the right method or media to make learning more interesting. The purpose of this study is to describe the TikTok application as music learning media from SMAN 1 Muara Enim, South of Sumatra. The research method used was a descriptive qualitative research method. This research was conducted in Perumahan Bumi Eraska Blok E7 no 12. The researcher got the data from observation of the learning outcomes of students and teacher of SMAN 1 Muara Enim South Sumatra, through Youtube and the TikTok application. The time of this research was conducted from March to June. Data collected were the result of interviews, literature, observation, and documentation. The result of this research indicates that the TikTok application can be used as a music learning medium. In utilizing the TikTok application there must be appropriate steps and methods to achieve learning objectives. there are positive effects in the use of the TikTok application at SMAN 1 Muara Enim, namely can make students get more confidence in the music subject, familiarizing students with the use of technology 4.0 especially in the music subject, increasing student interaction during distance learning, making it easier for teachers and students with its features to make music learning videos, make students more interactive, and as a promotional tool for the school.
\end{abstract}

Keywords: Learning, Media, TikTok, Application, Music.

Abstrak: Berlangsungnya kondisi pandemi hingga sekarang, menyebabkan proses pembelajaran harus dilakukan secara daring. Pembelajaran secara daring terkesan membosankan karena metode dan media pembelajaran daring yang diterapkan kurang kreatif dan bervariasi. Ketidakpiawaian guru dalam penggunaaan teknologi menjadi salah satu penyebab pembelajaran menjadi membosankan, sehingga sekolah dan guru berupaya mencari metode atau media yang tepat untuk menyampaikan pembelajaran agar lebih menarik. Tujuan Penelitian ini adalah untuk mendeskripsikan pemanfaatan aplikasi TikTok sebagai media pembelajaran musik pada SMAN 1 Muara Enim, Sumatera Selatan. Metode Penelitian yang digunakan adalah deskriptif kualitatif. Penelitian ini dilakukan di Perumahan Bumi Eraska Blok E7 no 12. Peneliti melakukan pengamatan terhadap hasil pembelajaran peserta didik serta Guru SMAN 1 Muara Enim Sumatera Selatan melalui Youtube dan Aplikasi TikTok. Waktu penelitian dilakukan dari bulan Maret - Juni 2021. Data yang dikumpulkan berupa wawancara, kajian pustaka, observasi, serta dokumentasi. Hasil penelitian ini menunjukan bahwa aplikasi TikTok dapat dimanfaatkan sebagai media pembelajaran musik. Dalam pemanfaatan aplikasi TikTok harus terdapat langkah dan metode yang tepat untuk mencapai tujuan pembelajaran. Selain itu terdapat efek positif dalam pemanfaatan aplikasi TikTok di SMAN 1 Muara Enim, yaitu menumbuhkan rasa percaya diri peserta didik dalam bidang musik, membiasakan peserta didik dalam penggunaan teknologi 4.0 terutama dalam bidang seni musik, meningkatkan interaksi peserta didik selama pembelajaran jarak jauh, mempermudah guru dan peserta didik dengan fitur - fiturnya untuk membuat video pembelajaran musik, peserta didik lebih interaktif, dan sebagai alat promosi bagi pihak sekolah.

Kata Kunci: Pembelajaran, Media, Aplikasi, TikTok, Musik

Article info:

Received: 21 July 2021

Reviewed: 18 November 2021

Accepted: 01 December 2021 


\section{PENDAHULUAN}

Era globalisasi atau sering disebut dengan era 4.0 adalah era dimana penggunaan teknologi di dunia ini merupakan hal yang sudah seharusnya menjadi kebiasaan dalam berinteraksi dan berkomunikasi (Setyowati, 2021). Dengan adanya kemudahan teknologi meluaskan jaringan komunikasi tanpa batas antar manusia, antar instansi, antar bangsa maupun antar negara. Dari hal tersebut diperlukan langkah untuk menghadapi era 4.0 ini, seperti mempelajari tren teknologi yang saat ini berkembang. Di tahun 2019 sebuah virus varian baru menyerang seluruh dunia yaitu Korona virus (covid 19). Penyebaran yang cepat dari korona virus menyebabkan pemerintah Indonesia menerapkan kebijakan Pembatasan Sosial Berskala Besar (PSBB) di tahun 2020, dan di tahun 2021 pemerintah mengeluarkan lagi kebijakan Penerapan Pembatasan Kegiatan Masyarakat (PPKM) untuk menekan penyebaran covid-19. Segala aktivitas diluar rumah dibatasi baik bekerja, berkumpul, belajar, bermain, dan lainnya.

Teknologi sangatlah berperan di keadaan pandemi seperti ini, dengan kemutakhiran teknologi segala pekerjaan, bertemu, dan bahkan pendidikan dapat dilakukan walaupun tidak bertemu secara langsung (Saputra, 2021). Dalam pendidikan di tengah pandemi ini, teknologi diperlukan untuk menunjang kegiatan pembelajaran daring. Pembelajaran daring berasal dari kata pembelajaran dan daring. Pembelajaran adalah suatu sistem yang didalamnya terdapat komponen-komponen untuk dapat menjalankan sistem tersebut. Komponen-komponennya adalah tujuan, isi, metode atau strategi pembelajaran, media dan sumber belajar serta evaluasi hasil belajar (Miftah, 2013). Daring adalah keadaan di mana perangkat elektronik terhubung dengan internet. Dari pernyataan tersebut maka pembelajaran daring adalah sebuah sistem yang di dalamnya terdapat tujuan, isi, metode atau strategi pembelajaran, media dan sumber belajar, serta evaluasi hasil belajar, dengan menggunakan perangkat elektronik yang terhubung dengan internet sebagai alatnya.

Kini dengan pembelajaran daring guru mempunyai tuntutan baru, yaitu menguasai penggunaan teknologi guna menunjang kegiatan pembelajaran di kelas (Saputra, 2020). Guru diharuskan mampu mengoprasikan perangkat lunak penunjang pembelajaran, seperti memakai atau membuat media pembelajaran yang mendukung pembelajaran daring. Media pembelajaran merupakan suatu perangkat yang dapat digunakan untuk menyalurkan pesan, sehingga dapat merangsang pikiran, perasaan, perhatian, dan minat peserta didik untuk belajar (Tafonao, 2018). Namun yang terjadi pada pembelajaran daring terutama tingkat SMA, di mana guru masih menggunakan metode yang sama dengan pembelajaran luring, sehingga semakin hari peserta didik merasa bosan dalam mengikuti kegiatan pembelajaran daring. Lain halnya dengan guru yang menguasai teknologi, contoh pelajaran seni budaya materi musik tradisional dapat dibawakan guru dengan bermacam-macam variasi metode. Seperti halnya guru dapat meminta peserta didik untuk mengunduh aplikasi $e$-gamelan sebagai penunjang pembelajaran musik tradisional.

Pemanfaatan teknologi merambah hampir di semua bidang keilmuan. Tidak terkecuali dalam bidang musik. Untuk melakukan berbagai aktifitas apapun dalam bidang musik di masa pandemi seperti ini, berbagai aplikasi yang dihasilkan oleh teknologi yang tinggi sangat diperlukan. teknologi jelas akan sangat membantu peningkatan mutu pendidikan, terutama di bidang musik. Salah satu contohnya adalah pemanfaatan teknologi seperti media sosial juga dapat digunakan guru sebagai variasi dalam kegiatan pembelajaran daring (Saputra, 2021) di tingkat SMA. Menurut Barnes, media sosial merupakan sebuah aplikasi yang digunakan untuk berinteraksi antara satu sama lain dan dapat membangun serta meningkatkan hubungan sosial (Damota \& Uninversity, 2019). Penggunaan media sosial dalam pembelajaran dilakukan guna menciptakan kegiatan belajar mengajar yang membuat peserta didik dapat mengikuti pembelajaran dengan baik.

SMAN 1 Muara Enim merupakan sekolah di Provinsi Sumatera Selatan yang memanfaatkan teknologi digital dalam masa pandemi ini sebagai salah satu media dalam pembelajaran musik di sekolah. Penggunaan media sosial dalam kegiatan pembelajaran musik di SMAN 1 Muara Enim Sumatera Selatan tentunya menjadi salah satu cara agar peserta didik dapat mengikuti kegiatan belajar mengajar dengan baik. Media sosial yang digunakan SMAN 1 Muara Enim Sumatera Selatan dalam kegiatan pembelajaran daringnya, adalah 
aplikasi TikTok. Aplikasi tersebut merupakan sebuah media sosial dengan mengunggah video singkat yang berfungsi sebagai sarana hiburan, tempat mengekspresikan diri, dapat membangun kreatifitas, serta mendapatkan popularitas bagi pengguna (Deriyanto \& Qorib, 2018).

Alasan mengapa TikTok menjadi media sosial yang digunakan untuk pembelajaran musik di SMAN 1 Muara Enim, karena TikTok sangat diminati oleh masyarakat di Indonesia terutama di kalangan anak-anak muda seusia anak SMA. Faktor terbesar mengapa aplikasi ini sangat populer adalah fitur-fitur dalam aplikasi TikTok dianggap menarik,mudah, selain itu penggunaan kuota internet terjangkau untuk semua kalangan dibandingkan aplikasi lain. Disebutkan kompas.com, bahwa hanya membutuhkan dana sebesar Rp 2.700, seseorang bisa mendapakan paket data yang lebih dari cukup untuk bermain TikTok. Paket data yang murah ini merupakan hasil dari kerjasama TikTok dengan beberapa provider di Indonesia (Kompas, 2019). Selain itu, keputusan SMAN 1 Muara Enim menggunakan aplikasi TikTok sebagai media pembelajaran, merupakan salah satu langkah untuk memenuhi kebijakan Merdeka Belajar. Kebijakan Merdeka Belajar adalah sebuah program dari Kementrian Pendidikan dan Kebudayaan yang mendukung sistem pendidikan berbasis Teknologi 4.0 (Sekolah Dasar, 2020).

Penggunaan TikTok pada kegiatan pembelajaran sangat banyak manfaatnya, terutama dalam pembelajaran musik. Terdapat banyak fitur yang mendukung pembelajaran musik pada aplikasi TikTok. Seperti membuat video materi pembelajaran musik yang menarik dengan menambahkan efek - efek serta latar musik di video pembelajaran sesuai keinginan pengguna, selain itu terdapat banyaknya pilihan musik untuk mengiringi bernyanyi pada aplikasi TikTok bahkan lagu daerah, pada aplikasi TikTok pengguna juga dapat melakukan duet bernyanyi atau bermain musik dengan teman ataupun artis terkenal. Di SMAN 1 Muara Enim Sumatera Selatan penggunaan aplikasi TikTok sebagai media pembelajaran musik dirasa sangat efektif, guru dan peserta didik SMAN 1 Muara Enim menggunakan variasi dalam fitur pada aplikasi TikTok untuk menambahkan efek dan latar belakang musik pada video singkat presentasi materi pembelajaran musik. SMAN 1 Muara Enim juga melakukan praktek musik dengan menggunakan TikTok sebagai media membuat dan membagikan video bernyanyi, bermain alat musik, bahkan duet memainkan musik secara jarak jauh dilakukan oleh guru dan peserta didik SMAN 1 Muara Enim. Hal ini membuat TikTok menjadi media sosial yang sangat membantu kegiatan pembelajaran di sekolah SMAN 1 Muara Enim Sumatera Selatan.

\section{METODE}

Jenis penelitian yang digunakan dalam penelitian ini adalah metode penelitian kualitatif dengan metode deskriptif. Kualitatif deskriptif adalah penelitian yang mempunyai data berupa kata, kalimat atau gambar yang memliki makna yang memberikan pemahaman (Nugrahani, 2014). Dalam hal ini, peneliti mengumpulkan data terkait Aplikasi TikTok, pembelajaran, media pembelajaran, dan metode pembelajaran terkait penelitian. Hasil pengumpulan data tersebut akan diringkas, dianalisis, serta digambarkan untuk menjawab pertanyaan terkait pemanfaatan TikTok sebagai Media Pembelajaran Musik di SMAN 1 Muara Enim Sumatera Selatan.

\section{HASIL DAN PEMBAHASAN}

\section{Langkah guru SMAN 1 Muara Enim Sumatera Selatan dalam Menentukan TikTok Sebagai Media Pembelajaran Musik.}

Pertama guru melakukan observasi. Guru melihat bahwa aplikasi TikTok menjadi aplikasi yang paling banyak diunduh oleh peserta didik SMAN 1 Muara Enim Sumatera selatan, sehingga guru menganggap bahwa TikTok dapat menjadi salah satu alternatif media pembelajaran dalam pembelajaran daring di era 4.0 ini. Proses selanjutnya adalah Guru mempelajari Aplikasi TikTok. Mulai dari kegunaannya, penggunaannya, serta efek positif dan negatif dari aplikasi TikTok jika digunakan sebagai media pembelajaran. Setelah menguasai aplikasi tersebut, guru dapat memulai penyuluhan kepada peserta didik bagaimana menggunakan TikTok yang baik dan benar sebagai media pembelajaran. Guru menjelaskan secara rinci kepada peserta didik seperti apa kegunaannya, bagaimana menggunakannya, serta efek positif dan negatif dari penggunaan TikTok dalam pembelajaran. Diharapkan peserta didik paham dan dapat menggunakan aplikasi TikTok untuk belajar dan mengumpulkan tugas-tugas yang diberikan dalam pembelajaran musik; serta diharapkan ketertarikan minat peserta didik dapat termotivasi. Dengan langkah yang diberikan tersebut, guru dan peserta didik tidak lagi kesulitan dalam menggunakan TikTok 
sebagai media pembelajaran musik di kelasnya. Selama penggunaan TikTok sebagai media pembelajaran musik bimbingan dan pengawasan guru tetap harus dilakukan agar pembelajaran berjalan sesuai tujuan pembelajaran.

Berikut ini adalah skema langkah-langkah dalam menentukan penggunaan aplikasi TikTok sebagai media pembelajaran musik di SMAN 1 Muara Enim:

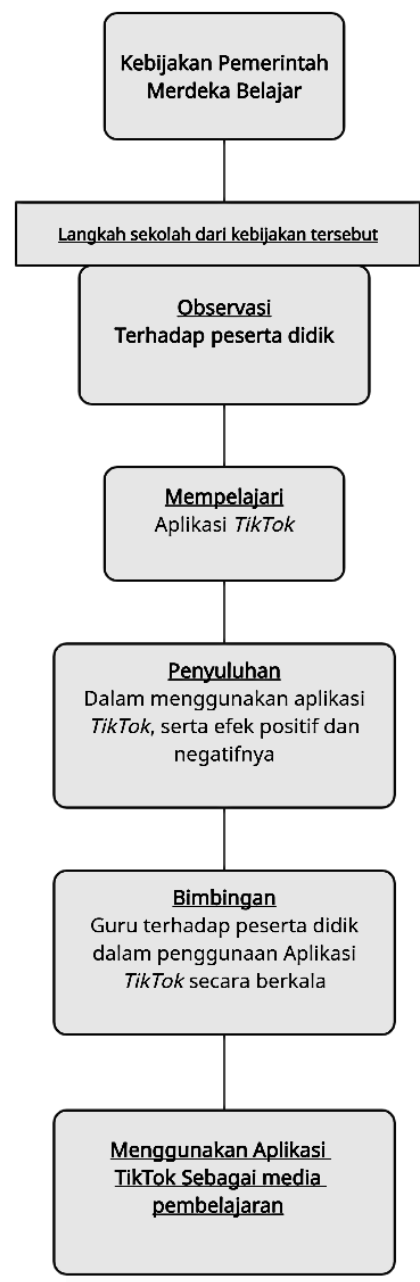

Gambar 1. Langkah-langkah dalam menentukan Aplikasi TikTok sebagai media pembelajaran.

Implementasi Aplikasi TikTok sebagai Media Pembelajaran Musik di SMAN 1 Muara Enim Sumatera Selatan.

1) Guru

Pemanfaatan TikTok SMAN 1 Muara Enim sangat bervariasi jenisnya, masing-masing guru mempunyai kreatifitas untuk menyampaikan materinya dalam video. Pertama, video pembelajaran berisi materi dalam bentuk power point yang ditambahkan latar lagu atau suara. Kemudian guru juga menjelaskan dengan
Kreasi monolog dan visual menggunakan animasi. Selain itu, untuk memberikan contohcontoh aplikasi TikTok juga digunakan guru agar peserta didik lebih memahami dan mengerti. Dalam hal ini guru menggunakan aplikasi TikTok untuk pembelajaran praktik Tari dan musik daerah. Guru membuat video pembelajaran tari dan lagu daerah dalam bentuk power point dan agar lebih menarik digunakan musik pengiring. Di video selanjutnya, guru mencontohkan seperti apa tarian tersebut dan memasukan lagu latar yang sesuai dengan jenis tarian dalam video.

Setelah menjelaskan serta mencontohkan materi pembelajaran tari dan lagu daerah. Guru kemudian memberikan penugasan kepada peserta didik. Guru memaparkan hal - hal terkait penugasan pada zoom meeting kemudian dikirimkan juga ke media whatsapp agar tercatat pada perangkat peserta didik. Pada zoom meeting dan whatsapp, peserta didik diminta untuk membuat sebuah video yang berkaitan dengan materi yang sudah dipelajari. Peserta didik diberikan kebebasan untuk memilih pilihan yang sudah ditentukan oleh guru untuk membuat kontennya masing masing. Terdapat tiga pilihan yang diberikan guru. Pertama, membuat video pembelajaran power point atau monolog terkait tari dan musik daerah, kedua melakukan praktek tari dan musik daerah, ataupun ketiga membuat riasan penari daerah.

Kemudian pada paparan zoom meeting dan whatsapp guru memberikan tenggang waktu pengerjaan kepada peserta didik yaitu setelah 1 minggu pengerjaan. Guru membebaskan pakaian peserta didik selama sesuai dengan tema yang peserta didik ambil. Setelah peserta didik mengunggah hasil videonya. Peserta didik diminta untuk mengkomunikasikan kepada guru dan peserta didik lainnya melalui grup whatsapp kelas. Hasil video pembelajaran peserta didik akan disaksikan bersama-sama pada pertemuan seni budaya selanjutnya pada zoom meeting, untuk diberikan komentar oleh guru serta peserta didik lainnya.

2) Peserta Didik

Pertama peserta didik memilih dari penugasan yang sudah ditentukan yaitu tentang tari dan musik daerah. Setelah itu peserta didik membuat video. Beberapa peserta didik melakukan pengambilan video langsung pada aplikasi TikTok agar lebih cepat untuk digubah, namun kebanyakan peserta didik membuat video 
diluar aplikasi TikTok agar video yang dihasilkan lebih baik lagi. Langkah selanjutnya adalah menggubah serta menambahkan fiturfitur pada Aplikasi TikTok. Beberapa peserta didik juga menggunakan aplikasi tambahan untuk mempermudah serta memperindah video sebelum diunggah ke aplikasi TikTok, contohnya seperti aplikasi Inshot sebuah aplikasi untuk menggubah video.

Selanjutnya peserta didik mengunggah video pada aplikasi TikTok dilengkapi dengan \#videopembelajaran dan \#rianpuspitasari1 sebagai penanda. Peserta didik juga harus menambahkan FYP (For Your Page) pada keterangan agar video pembelajaran yang dibuat dapat ditonton oleh pengguna TikTok lainnya diluar SMAN 1 Muara Enim Sumatera Selatan. Terakhir peserta didik diminta untuk mengkomunikasikan link hasil penugasan kepada guru dan peserta didik lainnya. Kemudian video hasil peserta didik akan ditonton bersama-sama dengan peserta didik lainnya di pertemuan selanjutnya menggunakan Zoom Meeting.

Kebanyakan dari peserta didik membuat video pembelajaran musik dengan menjelaskan power point tentang kesenian daerah dengan ditambahkan latar musik. Sedikit sekali peserta didik yang melakukan praktek pada video penugasan kesenian daerah di aplikasi TikTok. berdasarkan hasil wawancara dengan peserta didik SMAN 1 Muara Enim, hal ini dikarenakan kebanyakan peserta didik kurang yakin akan menunjukan kemampuannya untuk membuat video praktek bermain musik atau menari daerah. Terdapat 300 video yang sudah di unggah oleh peserta didik SMAN 1 Muara Enim Sumatera Selatan menggunakan \#rianpuspitasari1. \#rianpuspitasari1 adalah sebuah hashtag atau penanda pada keterangan video. Kegunaan hashtag adalah untuk mengelompokan konten agar memudahkan pencarian terhadap video pembelajaran peserta didik SMAN 1 Muara Enim. Total penonton pada semua video mencapai 4,2 juta penonton, dan rata - rata jumlah suka pada tiap video peserta didik adalah kurang lebih 300 suka per video.

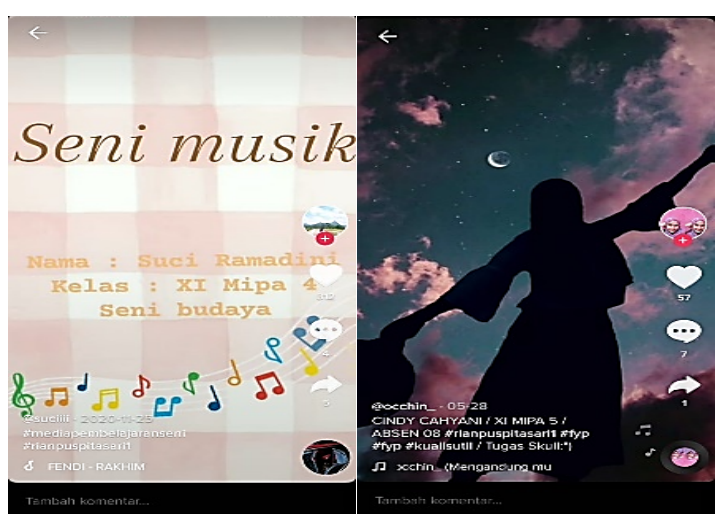

Gambar 2. Foto peserta didik pertama kali menggunakan TikTok (kiri Sumber: @suchi dan@ochhinTikTok kelas 11 SMAN 1 Muara Enim melalui aplikasi TikTok pada 17 Juni 2021 pukul 20.08 WIB.

\section{Pemanfaatan Aplikasi TikTok sebagai Media Pembelajaran.}

a. Guru

Pemanfaatan TikTok sebagai media pembelajaran musik bagi guru SMAN 1 Muara Enim dirasa sangat tepat. Aplikasi TikTok sangat membantu guru selama masa pembelajaran jarak jauh. Dengan aplikasi TikTok, guru dapat membuat sebuah media pembelajaran dalam bentuk video yang sangat variatif dan menarik. Hal ini sesuai dengan pernyataan Listia Nadjadja bahwa aplikasi adalah sebuah program untuk memenuhi visi pengguna (Natadjaja, 2013). Selain itu dalam pemanfaatan Aplikasi TikTok terdapat efek positif bagi guru SMAN 1 Maura Enim, yaitu:

1) Guru lebih mudah untuk memotivasi peserta didik.

Selama pembelajaran daring, peserta didik kurang termotivasi karena tidak mempunyai rasa kompetisi seperti pada pembelajaran tatap muka secara langsung. Contoh dulu dalam penugasan selama pembelajaran daring tugas seni budaya biasa dikirimkan langsung ke guru melalui google classroom. Hal ini membuat peserta didik tidak melihat hasil penugasan satu sama lain, sehingga tidak ada rasa ingin lebih baik karena peserta didik merasa tidak mempunyai kompetitor. Dengan penggunaa aplikasi TikTok, rasa untuk berkompetisi muncul. Hal tersebut dikarenakan hasil kreasi tiap peserta didik dapat diakses, diamati, dan bahkan dikomentari oleh peserta didik lainnya. Dengan hal ini, guru akan lebih mudah untuk memotivasi peserta didik untuk menghasilkan karya yang lebih baik lagi. 
2) Guru lebih mudah untuk menganalisis minat dan bakat peserta didik selama pembelajaran jarak jauh.

Pembelajaran jarak jauh sangat menyulitkan guru untuk melihat seperti apa kondisi peserta didik. Guru sulit mengembangkan minat dan bakat peserta didik. Dengan pemanfaatan TikTok, guru dapat melihat lebih jelas seperti apa bakat dan minat tiap peserta didik. Contoh dengan aplikasi TikTok guru dapat menganalisa bahwa peserta A mempunyai bakat menari namun kurang dalam penggubahan. Sementara peserta B sangat baik dalam gubahan sementara bakat seni tari ataupun musiknya kurang. Dengan hal seperti, ini guru bisa mendapatkan hasil analisis, yang sangat berguna untuk mengembangkan peserta didik kedepannya.

3) Guru lebih mudah melakukan interaksi dengan peserta didik.

Dengan aplikasi TikTok, guru dan peserta SMAN 1 Muara Enim menjadi lebih sering berinteraksi di kolom komentar video pembelajaran peserta didik ataupun guru. Dalam kegiatan pembelajaran daring dengan menggunakan media whatsapp atau google classroom, peserta didik dirasa pasif dalam mengikuti pembelajaran. Sementara dengan menggunakan aplikasi TikTok, peserta didik lebih sering berkomunikasi dengan guru atapun sesamanya.

4) Mempermudah guru dalam menyampaikan materi pembelajaran.

Dengan aplikasi TikTok, guru dipermudah untuk menyampaikan materi. Dengan fitur-fitur aplikasi TikTok guru dipermudah untuk menjabarkan materi lebih menarik atapun dipermudah dari segi latar musik dan proses gubahan untuk mempraktekan pembelajaran seni.

5) Sebagai salah satu langkah guru untuk mengaplikasikan sistem pendidikan 4.0 sesuai kebijakan Merdeka Belajar.

Pemanfaatan aplikasi TikTok sebagai media pembelajaran dapat menjadi salah satu opsi guru untuk menjalankan kebijakan merdeka belajar. Dengan penggunaan yang berbasis teknologi serta sumber informasi yang banyak, dapat menjadikan aplikasi TikTok sebagai perangkat untuk mensukseskan kebijakan Merdeka belajar. Selain efek positif yang membuat aplikasi TikTok menjadi media pembelajaran musik yang tepat untuk guru
SMAN 1 Muara Enim, terdapat juga efek negatif dari penggunaan aplikasi TikTok sebagai media pembelajaran bagi guru, yaitu dimana guru tidak bisa memantau apa yang dilihat peserta didik pada penggunaan TikTok di luar jam pelajaran. Hal ini peneliti anggap merugikan, karena peserta didik dapat melihat konten-konten negatif pada aplikasi TikTok dan mungkin akan peserta didik aplikasikan atau mencoba pada dirinya. Hal ini tentu akan merugikan guru dalam kegiatan pembelajaran karena perubahan sikap peserta didik yang negatif dari kontenkonten yang tidak mendidik.

b. Peserta Didik

Pemanfaatan aplikasi TikTok sebagai media pembelajaran musik pada peserta didik dirasa sangat tepat. Dengan pemanfaatan aplikasi TikTok peserta didik sangat dimudahkan dengan fitur-fitur untuk membuat video penugasan terkait pembelajaran seni budaya. Contohnya dalam menginput lagu peserta didik cukup memasukan latar musik pada bagian gubahan video aplikasi TikTok. Selain itu, peserta didik kebanyakan sudah terbiasa dengan pemakaian aplikasi TikTok sebagai media pembelajaran. Seperti yang diketahui aplikasi TikTok banyak dipakai oleh kalangan remaja di Indonesia. Sehingga dalam pengaplikasian TikTok menjadi media pembelajaran bagi peserta didik bukanlah hal yang sulit.

Pemaanfatan aplikasi TikTok juga memunculkan perubahan sikap yang positif dari peserta didik. Berikut ini peneliti uraikan perubahan sikap peserta didik dengan menggunakan TikTok sebagai media pembelajaran musik di SMAN 1 Muara Enim.

1) Secara psikologi peserta didik lebih percaya diri.

Menurut Lauster, kepercayaan diri adalah sikap atau keyakinan akan melakukan tindakan. sehingga pelaku tidak menjadi cemas atas tindakannya tersebut (Syam \& Amri, 2017). Dengan respon positif dari teman serta guru terhadap video yang diunggah peserta didik pada aplikasi TikTok akan meningkatkan rasa percaya diri peserta didik. Hal ini yang terjadi pada SMAN 1 Muara Enim dimana terdapat respon positif untuk mendukung karya temannya. Hal ini dilihat dari jumlah suka video peserta didik. Rata-rata peserta didik mempunyai tiga ratus lebih suka dalam satu video yang dibuat. 
2) Peserta didik lebih antusias dengan pembelajaran musik menggunakan aplikasi TikTok.

Rasa antusiasme akan meningkat karena penggunaan aplikasi yang digemari peserta didik. Hal ini dapat dilihat dari unggahan video dengan \#rianpuspitasaril mencapai tiga ratus video dari jumlah peserta didik yang menggunakan seratus lima puluh peserta didik. Bila kita hitung berarti satu peserta didik mengupload kurang lebih dua video.

3) Peserta didik kini lebih mengapresiasi karya temannya.

Peneliti melihat dari tiga ratus video yang terunggah, penonton video dengan \#rianpuspitasari1 mencapai empat juta dua ratus ribu penonton, dan jumlah suka tiap video 300400 pervideo peserta didik. Dari data tersebut peneliti melihat bahwa jumlah suka pada tiap video melebihi total peserta didik kelas sebelas yang menggunakan aplikasi TikTok sebagai media pembelajaran. Hal ini berarti, peserta didik mengapresiasi video pembelajaran yang dibuat temannya. Selain itu, dengan proses pembuatan video yang dirasakan peserta didik menjadi salah satu faktor peserta didik lebih mengapresiasi karya temannya, di mana peserta didik mengetahui kesulitan dan hambatan apa saja yang dirasakan temannya selama pembuatan tugas melalui aplikasi TikTok.

4) Meningkatnya kemampuan menggunakan teknologi bagi peserta didik dan guru meningkat dengan penggunaan TikTok.

Dari hasil penelitian, peneliti mendapatkan bahwa terdapat peningkatan kemampuan menggunakan teknologi bagi guru dan peserta didik SMAN 1 Muara Enim Sumatera Selatan. Di era ini tentunya penggunaan teknologi menjadi hal yang penting untuk peningkatan kualitas sumber daya manusia di Indonesia. Dengan TikTok peserta didik dan guru SMAN 1 Muara Enim dibiasakan menggunakan teknologi sembari mengerjakan tugas pembelajaran. Hal ini sejalan dengan prinsip dari merdeka belajar dimana guru harus bisa memberikan penugasan yang berbasis teknologi untuk meningkatkan kualitas peserta didik.

5) Peserta didik lebih interaktif dengan menggunakan TikTok di tengah pembelajaran jarak jauh.

Di tengah pembelajaran jarak jauh ini, pertemuan pembelajaran dengan Zoom Meeting membuat peserta didik sangat pasif dalam mengikuti pembelajaran. Dengan TikTok kini peserta didik lebih aktif untuk berinteraksi sesamanya. Menurut narasumber bahkan peserta didik yang sangat pasif dapat berkomentar pada aplikasi TikTok. Dari hal ini, walaupun peserta didik tidak bertemu secara langsung dengan TikTok diharapkan peserta didik dapat aktif dalam berinteraksi dengan sesama. Kemudian terdapat juga efek negatif dari penggunaan aplikasi TikTok sebagai media pembelajaran bagi peserta didik, yaitu menyebabkan tidak terfokusnya konten pada aplikasi TikTok untuk pembelajaran music, menyebabkan peserta didik tidak fokus dengan penggunaan TikTok sebagai media belajar. Selain itu, Efek negatif dari konten yang tidak mendidik dapat menyebabkan perubahan sikap negatif pada peserta didik. Contoh konten dengan memuat bahasa kasar. Hal ini dapat ditiru oleh peserta didik dan dia aplikasikan kepada lingkungan sekitarnya.

\section{SMAN 1 Muara Enim Sumatera Selatan.}

Pemanfaatan aplikasi TikTok dalam kegiatan pembelajaran musik memberikan efek positif kepada sekolah. Berikut ini peneliti akan menguraikan efek positif dari pemanfaatan TikTok sebagai media pembelajaran sekolah.

1) Sebagai salah satu langkah sekolah melakukan kegiatan pembelajaran 4.0 dalam kebijakan Merdeka Belajar.

Dalam kebijakan Merdeka Belajar, pihak sekolah diharapkan dapat memanfaatkan teknologi, guna menjalankan pembelajaran 4.0. untuk meningkatkan kemampuan sumber daya manusia di Indonesia. Pemanfaatan aplikasi TikTok dirasa menjadi salah satu langkah sekolah dalam menjalankan kebijakan Merdeka Belajar. Dengan pemanfaatan aplikasi TikTok, peserta didik dibiasakan dengan penggunaan teknologi yang secara tidak sadar dapat meningkatkan kemampuan peserta didik dalam hal informasi dan tekologi.

2) Sebagai media untuk mempromosikan pihak sekolah.

Dalam pemanfaatan aplikasi TikTok sebagai media pembelajaran, video yang dibuat peserta didik dan guru bukan hanya ditonton oleh warga SMAN 1 Muara Enim, melainkan seluruh pengguna TikTok dapat menyaksikan video yang dibuat oleh guru dan peserta didik SMAN 1 Muara Enim Sumatera Selatan. Dengan hal tersebut sekolah mendapatkan keuntungan yaitu dipromosikan oleh guru dan peserta didik lewat video yang mereka buat dan unggah. Bila adanya efek negatif bagi peserta 
didik seperti perubahan sikap yang mempengaruhi prestasi belajar, tentu akan berefek kepada pihak sekolah. Sekolah akan mengalami kemunduran jika guru lalai dalam menerapkan TikTok ke dalam pembelajaran. Oleh karena itu, sekolah harus mempunyai andil besar dalam kegiatan penggunaan TikTok seperti melakukan seminar mengenai pemanfaatan TikTok yang baik dan benar dalam kegiatan pembelajaran dengan pembicara yang menguasai bidang tersebut. Dengan beberapa paparan pembahasan peneliti katakan bahwa pemanfaatan aplikasi TikTok sebagai media pembelajaran musik di SMAN 1 Muara Enim Sumatera Selatan bagi guru, peserta didik, serta sekolah dirasa sangat tepat.

\section{KESIMPULAN}

Hasil penelitian menjabarkan bahwa Aplikasi TikTok dapat dimanfaatkan dengan baik pada pembelajaran musik SMAN 1 Muara Enim Sumatera Selatan. Aplikasi TikTok dapat menjadi salah satu media pembelajaran yang mendukung kebijakan kampus merdeka untuk menjalankan sistem pembelajaran 4.0 berbasis teknologi. Dalam pengimplementasian TikTok sebagai media pembelajaran musik, diperlukan beberapa langkah yang harus dilalui guru. Dengan berdasarkan kebijakan Merdeka Belajar. Guru harus melakukan beberapa langkah yaitu observasi, mempelajari, penyuluhan kepada siswa, dan yang terakhir adalah penggunaan aplikasi TikTok. Dengan penerapan langkah diatas, penggunaan TikTok sebagai media pembelajaran musik tetap dalam bimbingan dan pengawasan guru secara berkala agar pembelajaran berjalan sesuai tujuan pembelajaran serta dapat menghindari efek negatif saat penggunaan aplikasi TikTok sebagai media pembelajaran musik.

Aplikasi TikTok mempunyai banyak kelebihan dalam menunjang pembelajaran musik di SMAN 1 Muara Enim Sumatera Selatan, seperti banyak masyarakat menggunakan aplikasi TikTok khususnya, aplikasi TikTok mudah dioperasikan, fitur-fitur TikTok mendukung pembelajaran seni, serta mempunyai manfaat yang mendukung perkembangan peserta didik. Adapun kekurangan aplikasi TikTok adalah terlalu singkat durasi waktu pervideo. Dan ketidakfokusan TikTok dalam hal musik, sehingga dikhawatirkan peserta didik tidak fokus terhadap pembelajaran yang dilakukan menggunakan TikTok dikarenakan teralih dengan konten lainnya.

\section{DAFTAR PUSTAKA}

Damota, M. D., \& Uninversity, M. W. (2019). The Effect of Social Media on Society. New Media and Mass Communication, June, 611. https://doi.org/10.7176/nmmc/78-02

Deriyanto, D., \& Qorib, F. (2018). Persepsi Mahasiswa Universitas Tribhuwana Tunggadewi Malang Terhadap Penggunaan Aplikasi Tik Tok. JISIP: Jurnal Ilmu Sosial Dan Politik, 7(2), 77-83. www.publikasi.unitri.ac.id

Kompas. (2019, 03 15). penggunaan Kuota TikTok. Retrieved from Kompas.com.

Miftah, M. (2013). Fungsi, Dan Peran Media Pembelajaran Sebagai Upaya Peningkatan Kemampuan Belajar Siswa. Jurnal Kwangsan, $\quad 1(2), \quad 95$. https://doi.org/10.31800/jkwangsanjtp.v1n2.p95--105

Natadjaja, L. (2013). Rancangan Aplikasi Bidang Keilmuan Desain Komunikasi Visual pada Kegiatan Community Outreach Program. Nirmana, 14(1), 21-29. https://doi.org/10.9744/nirmana.14.1.21-29

Nugrahani, F. (2014). Metode Penelitian Kualitatif. Surakarta : Cakrabooks

Saputra, D. N. (2020). Penerapan Flipped Classroom Pada Pembelajaran Teori Musik Di Prodi Pendidikan Musik. PEDAGOGIA, 18(3).

doi:https://doi.org/10.17509/pdgia.v18i3.2 9537

Saputra, D. N. (2021). Learning Innovation Through Freedom Learning Management in Music Education Program. Education, Sustainability \& Society, 4(2): 43-49. doi:https://doi.org/10.26480/ess.02.2021.4 3.49

Saputra, D. N. (2021). Digital Platform's: Investigations in the Application of Music Practice Learning. JIRA: Jurnal Inovasi dan Riset Akademik, 2(6), 882-889. doi:https://doi.org/10.47387/jira.v2i6.171

Sekolah Dasar. (2020). Kebijakan Merdeka belajar KEMENDIKBUD. Retrieved from kemdikbud.co.id: ditpsd.kemdikbud.co.id

Setyowati, D. (2021, july 9). Bos Lippo Mochtar Riady Sebut Teknologi Digital Bukan Hal Baru. Retrieved from Katadata.co.id: https://katadata.co.id/desysetyowati/digital/ 
5e9a4c53e8849/bos-lippo-mochtar-riadysebut-teknologi-digital-bukan-hal-baru

Stephanie, C. (2020). Daftar Paket Internet TikTok dari Telkomsel, Mulai Rp 4.000. Kompas.Com.

https://tekno.kompas.com/read/2020/10/28
/11210087/daftar-paket-internet-TikTokdari-telkomsel-mulai-rp-4.000?page $=$ all

Tafonao, T. (2018). Peranan Media Pembelajaran Dalam Meningkatkan Minat Belajar Mahasiswa. Jurnal Komunikasi Pendidikan, 2(2), 103. https://doi.org/10.32585/jkp.v2i2.113 